\title{
Marian Nowak*
}

Lublin

\section{Tożsamość pedagogiki chrześcijańskiej}

Jednym z istotnych zagadnień każdej dyscypliny czy subdyscypliny jest jej specyfika i tożsamość. Zwykle są one wyznaczane i definiowane przez wskazanie na specyficzny dla danej dyscypliny lub subdyscypliny - jej przedmiot badań, na specyficzną jej problematykę, którą się zajmują i uprawiają jej przedstawiciele, na specyfikę jej uprawiania i prowadzenia badań, na niepowtarzalną historię jej rozwoju (na przestrzeni historii istnienia danej dyscypliny) i perspektywy jej rozwoju.

Jednym z pomocniczych działań w budowaniu tożsamości każdej dyscypliny jest także uprawianie analiz porównawczych danej dyscypliny z innymi obok niej istniejącymi i wskazywanie na jej specyfikę lub tożsamość w kontekście historii rozwoju, przedmiotu badań i metodologii innych dyscyplin.

Zagadnienie przedstawia się dość specyficznie, gdy chcemy mówić o tożsamości pedagogiki chrześcijańskiej jako jednej z subdyscyplin pedagogicznych. Tak sformułowany tytuł artykułu odsyła do wyznaczenia jej przedmiotu badań, jej metodologii, specyfiki jej rozwoju i jej odmienności i oryginalności - w odróżnieniu od innych dyscyplin. I w tym momencie spotykamy się z podstawową trudnością, związaną z takim podejściem do problematyki tożsamości pedagogiki chrześcijańskiej. Intuicyjnie bowiem z samego faktu istoty przesłania chrześcijańskiego zdajemy sobie sprawę, że problematyka pedagogiki chrześcijańskiej rozpościera się na wszelkie problemy związane $\mathrm{z}$ wychowaniem człowieka i ludzkim rozwojem oraz po-

* Ks. prof. dr hab. Marian Nowak jest kierownikiem Katedry Pedagogiki Ogólnej w Instytucie Pedagogiki Katolickiego Uniwersytetu Lubelskiego Jana Pawła II. 
wszechnością jej występowania. Odczytujemy też, że nie jesteśmy uczniami Chrystusa na tym świecie, aby się od tego świata oddzielać i separować, do czego często usilne poszukiwanie własnej tożsamości może prowadzić.

Jak to zatem ma być z pedagogiką chrześcijańską? - powinna ona wyraźnie określić swoją tożsamość i oryginalność czy też wpisywać się na zasadzie zaczynu ewangelicznego (zakwasu koniecznego do wyrabiania chleba) w każde dążenia do „czynienia człowieka bardziej człowieczym” (jak chciał tego już Arystoteles)? Nie ma na to pytanie zbyt łatwej i jednoznacznej odpowiedzi, jak sam Jezus Chrystus nie udzielał wyraźnych odpowiedzi na temat swojej misji, ale przygotowywał uczniów i otwierał ich umysły na nadejście Ducha Pocieszyciela, Który doprowadzi ich do całej prawdy (J 16, 13).

Spotykamy jednakże się z naleganiami ze strony wielu środowisk, podobnie jak te nalegania dotykały samego Jezusa: Jesteś tym Mesjaszem, czy też nie!? Ze sposobu odpowiedzi samego Jezusa, udzielonej na przykład uczniom samego Jana Chrzciciela, możemy czerpać inspirację do odpowiedzi na pytanie o tożsamość pedagogiki chrześcijańskiej. Jezus odpowiada uczniom Jana Chrzciciela powołując się na znaki, które charakteryzują Jego działalność: „Niewidomi wzrok odzyskują, chromi chodzą, trędowaci doznają oczyszczenia i głusi słyszą; umarli zmartwychwstają, ubogim głosi się Ewangelię" (Łk 7, 22).

Ponieważ wydaje się coraz bardziej odczuwana konieczność zdefiniowania i „,roboczego" przynajmniej określenia tożsamości pedagogiki chrześcijańskiej, wydaje się na podobieństwo opisanej sytuacji podjąć niektóre aspekty, będące znakami rozpoznawania tożsamości pedagogiki chrześcijańskiej, co czyni się intencją obecnego artykułu - w istocie dającego próbę zarysu głównych linii rozwoju tej problematyki, która wymagałaby dalszych pogłębionych analiz i opracowań.

W prezentacji zagadnienia, wychodząc od przesłanek historycznych, zostaną omówione także główne linie możliwe do podjęcia problemów związanych z tożsamością pedagogiki, która z racji interdyscyplinarnego charakteru jej badań (od biologicznych aspektów wychowania aż po teologiczne) mogą rodzić również szereg nieporozumień.

\section{Tożsamość pedagogiki jako dyscypliny wiedzy i tożsamość pedagogiki chrześcijańskiej jako jej subdyscypliny}

Gdy stawiamy problem tożsamości jakiejś dyscypliny, wiążemy go zwykle z zagadnieniem jej specyfiki, powstaje natychmiast kolejna trudność, którą możemy wyrazić w postaci pytań: Specyfiki czego?: Czy sa- 
mej działalności wychowawczej? Czy też specyfiki myślenia pedagogicznego?

Mówiąc o specyfice pedagogicznej działalności wychowawczej, czy o specyfice nauki, w tym ostatnim przypadku zwracamy zwykle uwage na przedmiot materialny i formalny danej nauki. Przedstawia się on różnie w odniesieniu do poszczególnych nauk, a nawet dla całych grup nauk, na przykład inaczej on jest pojmowany w odniesieniu do nauk przyrodniczych, jeszcze inaczej w relacji do nauk humanistycznych i społecznych, filozoficznych czy teologicznych.

Stefan Kunowski (1909-1977) specyfikę i tożsamość pedagogiki pojmuje jako wyznaczaną przez ukierunkowanie się na cel, rozumiany jako „dobro rozwojowe człowieka - nie aktualnie pojęte, lecz realizujące się w przyszłości, nastawione ku przyszłości - dzięki czemu człowiek może się doskonalić i osiagać kres procesu rozwoju"'.

Ks. Janusz Tarnowski (1919-2012) podkreśla w związku z tym celem: „Skoro pedagogika jest nauka, to ma wspólny dla wielu nauk przedmiot materialny dociekań: człowieka. Wyróżnia się jednak przedmiotem formalnym. Opracowuje ona mianowicie naukowo pozytywny sposób oddziaływania na człowieka w celu osiągnięcia pożądanego wyniku, np. rozwinięcia człowieczeństwa jednostki ludzkiej"2.

O ile, zdaniem S. Kunowskiego, w pedagogice należy przypisać pierwszorzędność rzeczywistości wychowania, co tym bardziej eksponuje (I dział) praktyczny charakter pedagogiki (konkretne doświadczenia rodziców, nauczycieli i wychowawców), będący w ogóle podstawą tworzenia wiedzy pedagogicznej, to nie można pomijać też roli i znaczenia opisu i badań tego doświadczenia, co czyni (II dział) pedagogika opisowa lub eksperymental$n a$, doświadczalnie badająca i odkrywająca na tej drodze prawidłowości i prawa rządzące przebiegiem zjawisk biologicznych, psychologicznych, kulturowych, socjologicznych itd., związanych z wychowaniem. Nad tym zaś należy umiejscowić trzeci jej dział - pedagogikę normatywna, która jest zainteresowana wartościami, celami, ideałami i normami wychowania, które ustala na podstawie przyjętej koncepcji (filozofii człowieka) i prowadzi do czwartego i najbardziej ogólnego działu, jakim jest naukowa pedagogika teoretyczna jako ogólna teoria rzeczywistości wychowania, która w oparciu o materiał empiryczny, eksperymentalny i normatywny dąży do stworzenia jednolitej teorii wszechstronnego rozwoju człowieka i jego uwarunkowań i w ten sposób, jako teoria, obiektywnie odtwarza cała rzeczywistość wychowawczq.

1 S. Kunowski, Podstawy współczesnej pedagogiki, Łódź 1981, s. 38.

2 J. Tarnowski, Jak wychowywać?, Warszawa 1993, s. 54. 


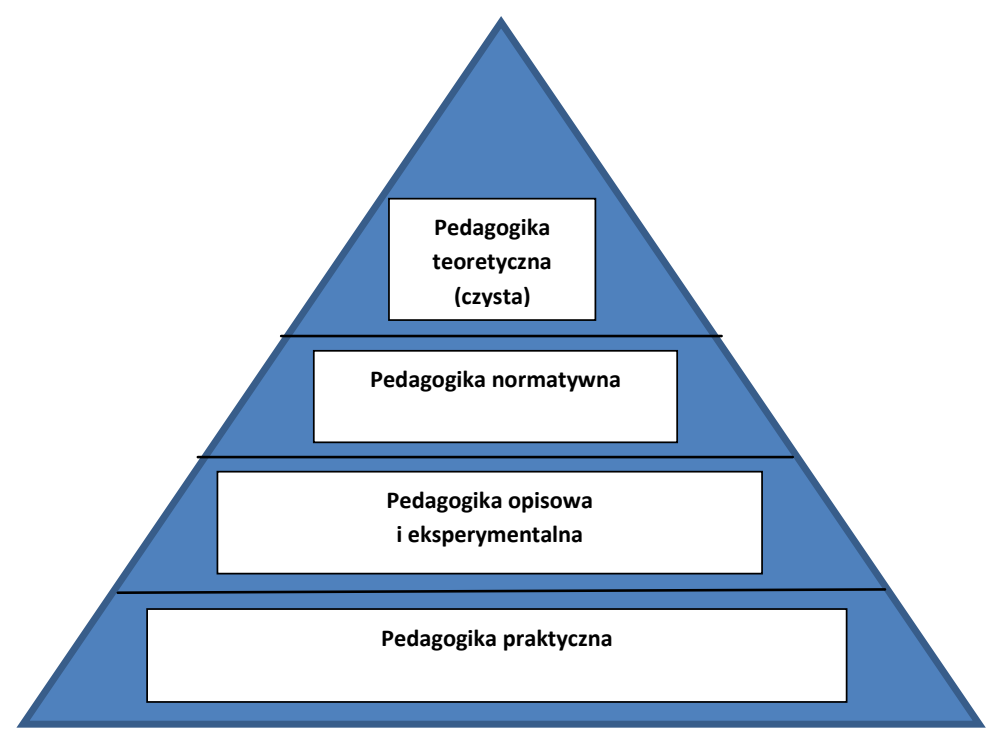

Schemat 1. Schemat wertykalnego układu działów pedagogiki i jej złożoności wg S. Kunowskiego

Złożona i wielowarstwowa struktura pedagogiki wskazuje na konieczność specyficznego podejścia w pedagogice, które pozwoliłaby na integralne ujęcie problematyki.

Nie są to problemy obce pedagogice w ogóle i mają one swoją odległą historię związaną z odkrywaniem w ramach badań pedagogiki ogólnej, czy też podstaw pedagogiki. Tego rodzaju badania dotyczą w istocie poszukiwania „pedagogicznej istoty”, czy też specyfiki przedmiotu badań pedagogiki i odnoszą się do jej tożsamości.

Wydaje się jednak, że dopiero zainteresowanie się indywidualizmem w XIX wieku, a następnie w XX wieku nurtami kolektywistycznymi, uświadomiło pedagogom, że człowieka nie można sprowadzić tylko do jednego z tych aspektów i to w tym kontekście problemowym i filozoficznym należałoby umiejscowić prace Martina Bubera (1878-1965) i Romano Guardiniego (1885-1968), poświęcone poszukiwaniom tożsamości pedagogiki, czy też specyfiki pedagogicznej:

Jednym z pierwszych wyraźnych studiów tego problemu było opracowanie Martina Bubera Über das Erzieherische (1927)³. W 1925 roku w Heidelbergu, na międzynarodowej konferencji pedagogicznej na temat: $W y$ -

${ }^{3}$ M. Buber, Über das Erzieherische, w: tenże, Rede über Erziehung, Heidelberg 1927, s. 11-40; także wydanie późniejsze: Reden über Erziehung, Heidelberg 1964. 
zwolenie twórczego potencjału dziecka, Buber wygłosił Mowe o specyficznie wychowawczym, która w rok później ukazała się drukiem pod podanym wyżej tytułem. W traktacie tym Buber wskazuje na relację wychowawczą jako typowo dialogiczną. Szczególną rolę w tej relacji Buber przypisuje wychowawcy, który winien w niej przywoływać Stwórcę, przez swoją obecność ratować i przywoływać oryginalny obraz Boży w człowieku.

Problem ten został podjęty przez Romano Guardiniego, również wpisującego się w poszukiwanie pedagogicznej autonomii młodej wówczas dyscypliny wiedzy - pedagogiki, w traktacie Podstawy pedagogiki (1928) ${ }^{4}$.

Pytanie, jakie postawiał sobie niegdyś Romano Guardini, brzmiało: „jaka jest istota faktu pedagogicznego? Na czym polega specyfika podejścia pedagogicznego, gdzie i w czym tkwiłaby owa niezależność oraz czym różniłaby się ona od tego, co specyficzne w medycynie, polityce, w naukach społecznych, etyce, religii itp." 5 .

Guardiniego interesuje również problem specyfiki i tożsamości pedagogiki w związku z poszukiwaniem specyficznie pedagogicznego aspektu i specyficznie pedagogicznych kategorii - jako podstawy teorii pedagogicznej.

W ustaleniach Guardiniego nie tyle chodziło o identyfikację szczególnej rangi problemów, ani też o metody czy techniki wychowania, lecz o najbardziej pierwotny i podstawowy dla wszelkiej działalności wychowawczej - impuls wychowania i podstawowe pedagogiczne kategorie, a przez nie o odkrywanie i dochodzenie do zrozumienia ludzkiej egzystencji z uwzględnieniem wszelkich uwarunkowań, także pozaracjonalnych i pozaintencjonalnych.

Dochodzenie do zrozumienia ludzkiej egzystencji wymaga wyraźnej pomocy wychowawczej, która opierając się na ludzkiej relacji do świata, ujętego w jego całości i integralności, zdolna jest prowadzić nas do konstatacji, że ostatecznie wszystko to, co wiąże się z wychowaniem, jest wpisane w tajemnicę stużenia, pomagania, uzdrawiania. Aby zaś tę właśnie pedagogiczną specyfikę i tożsamość wydobyć, nie można zadowolić się jednym aspektem lub jedyną przyjętą perspektywą patrzenia, lecz należałoby dążyć do ujęcia wielorakich aspektów i wątków, które stają się istotne w tym dziele.

${ }^{4}$ R. Guardini, Grundlegung der Bildungslehre, „Die Schildgenossen“ 4 (1928), s. 314 -339. Późniejsze wydania: Grundlegung der Bildungslehre. Versuch einer Bestimmung des Pädagogisch-Eigentlichen, Würzburg 1953 (fragment w thum. polskim Jana Koźbiała: Podstawy pedagogiki (1928), w: R. Guardini, Bóg daleki - Bóg bliski, Poznań 1991, s. 270-278).

${ }_{5}^{5}$ Tamże, s. 46-47; także M. Nowak, Profil pedagogiczny nauk o wychowaniu, Lublin 2012, s. 72n. 
Zdaniem Romano Guardiniego, specyfikę pedagogiki i jej tożsamość możemy rozpatrywać $\mathrm{w}$ trojakich relacjach, w których specyfika pedagogiczna pojawia się jako punkt przecięcia tych relacji. Mamy więc najpierw określenie: 1) tego, co gwarantuje tożsamość i określoność oraz stałość, 2) następnie mamy również coś dynamicznego - pewną gamę możliwości i tego, co nieprzewidywalne - egzystencja (dialog, spotkanie). Ten moment jest trudno ująć w pojęciach, gdyż jest on bardzo rzeczywisty i żywy; 3) w końcu jest trzeci moment - przedmiot z jego własnymi prawami, który należy przyjąć, czyli też wychowywać do właściwej relacji ze światem przedmiotów. W taki sposób dochodzimy do pedagogiki przedmiotu w przeciwieństwie do pedagogiki skoncentrowanej na podmiocie, $\mathrm{z}$ dwoma istotnymi perspektywami: z jednej strony mamy przyjęcie (np. wartości), z drugiej zaś stużbę im i poświęcenie się im.

Zdaniem teologa i filozofa Hansa Ursa von Balthasara (1905-1988) w takim ujęciu wychowania przez Guardiniego jest zawarte dążenie do ujmowania wychowania $\mathrm{w}$ jego integralności, w swoistym poszukiwaniu całości i złożoności rzeczywistości ${ }^{6}$, któremu poświęćmy naszą uwagę jako jednemu ze znaków tożsamości pedagogiki chrześcijańskiej.

\section{Tożsamość dyscyplinarna pedagogiki chrześcijańskiej wśród innych dyscyplin pedagogiki XXI wieku}

Nade wszystko wydaje się dość jasno przedstawiać tożsamość pedagogiki chrześcijańskiej, gdy wyjdziemy od jej nazwy i na ogół nie ma problemów z identyfikowaniem się z tą dyscypliną pedagogiczną określonej grupy pedagogów, czy określonej grupy problemów w niej analizowanych.

To właśnie w pracach i badaniach tych pedagogów pedagogika chrześcijańska przedmiotem swoich analiz czyni chrześcijańskie wychowanie człowieka, czyli proces w którym ci, którzy doświadczyli duchowego odrodzenia z wody i Ducha Świętego oraz pozostają w relacji z Bogiem, wspieraja innych i realizują w sobie obraz Chrystusa. $Z$ takim wychowaniem i refleksją nad nim mamy do czynienia wraz z przyjściem Chrystusa, chociaż korzenie tej myśli i tej praktyki tkwią bardzo wydatnie w nauczaniu i tradycji Starego Testamentu?

${ }^{6}$ H. Urs von Balthasar, Romano Guardini. Reform aus dem Ursprung, München 1970, s. 33 .

7 Zob. L. C. Blank Jr., Foreword, w: M. J. Anthony (red.), Introducing Christian Education. Foundations for the Twenty-first Century, Michigan 2001, s. 11-12. 
W te podstawy wpisuje się nade wszystko działalność samego Jezusa Chrystusa, związana z troska, aby upadłą ludzkość doprowadzić do Stwórcy i do pełni zbawienia, aby wszyscy mieli życie i mieli je w obfitości. Wpisuje się w nie również mandat misyjny Jezusa Chrystusa nadany uczniom i obejmujący czas, aż do Jego powtórnego przyjścia. Z zaangażowaniem i oddaniem tej właśnie misji uczniowie Jezusa zrzeszeni w Jego Kościele, ale także w wielorakich i związanych z uwarunkowaniami czasu i miejsca wspólnotach, stowarzyszeniach, instytucjach formalnych i nieformalnych, podejmowali i podejmuja działalność wychowawczą i refleksję naukową służącą wymienionym celom i zawsze wynikająca z serca Chrystusowego Kościoła (ex corde Ecclesiae) ${ }^{8}$.

Aby mówić o tożsamości pedagogiki chrześcijańskiej w XXI wieku, należy podjąć przynajmniej próbę ujęcia głównych linii przemian, jakie charakteryzują obecną sytuację. Rozpoczęte nowe stulecie i tysiąclecie zaznacza się wzrostem możliwości, ilości i form komunikacji międzyludzkiej, globalną ekonomią i rozwojem tak zwanego wolnego rynku oraz międzynarodowymi relacjami ${ }^{9}$. Te aspekty istotnie wpływają na życie nowych pokoleń i współuczestniczą w realizacji wychowania chrześcijańskiego oraz tworzenia pedagogiki chrześcijańskiej naszego czasu.

Wielokulturowość, naturalizm i relatywizm poddają ustawicznym próbom nasz system moralny i etyczny nawet w chrześcijańskiej Europie, niejednokrotnie wymagając z naszej strony „obrony tej nadziei, która jest w nas", jak nawoływał św. Piotr Apostoł (1 P 3, 15).

W obliczu tych trudności, jako chrześcijanie odnajdujący się w przywoływanej już misji powierzonej nam przez Chrystusa, nie możemy ulegać pokusie ustępstw w zakresie praktyki czy metodologii, lecz mamy kierować nasz wzrok na cel, jakim jest ukazanie, czynienie i prowadzenie każdej osoby ku pełni Chrystusowej (Kol 1, 28). Jako najbardziej wyróżniające cechy (znaki rozpoznawcze) tej metodologii, ale też i praktyki w odniesieniu do wychowania, możemy wymienić nade wszystko integralność i ukierunkowanie na urzeczywistnianie człowieczeństwa w człowieku, które wymagają bliższego przyjrzenia się im i omówienia.

\subsection{Integralność i uniwersalność jako wyznaczniki tożsamości chrześcijańskiej myśli pedagogicznej}

Realizacja tej misji wymaga szerokiego oparcia się na podstawach historycznych (sięgając do tradycji myśli filozoficznej o wychowaniu nawet

${ }^{8}$ Taki jest tytuł dokumentu papieża Jana Pawła II, Konstytucja apostolska $O$ uniwersytetach katolickich (Ex corde Ecclesiae), promulgowanego 15 sierpnia $1990 \mathrm{r}$.

9 Zob. M. J. Anthony, Introduction, w: tenże (red.), dz. cyt., s. 14. 
czasów starożytnych) i teologicznych (ze szczególnym uwzględnieniem nowości chrześcijańskiego przesłania także pedagogicznego), z uwzględnieniem wkładu nauk społecznych i humanistycznych (socjologii, psychologii, pedagogiki, antropologii) oraz przekonania o potrzebie także akademickiej dyscypliny o chrześcijańskim wychowaniu wśród innych dyscyplin pedagogicznych $^{10}$.

Początki takich badań zorientowanych na wyodrębnienie tożsamości pedagogiki chrześcijańskiej jako jednej z dyscyplin nauk pedagogicznych znajdujemy u Ottona Willmanna (1839-1920). Otto Willmann, jako jeden z pierwszych pedagogów katolickich wśród wielkich myślicieli niemieckich i jeden z twórców pedagogiki społecznej, przez swoją aktywność naukową położył solidne podstawy nie tylko dla zbudowania pedagogiki naukowej, wskazując na jej związki z filozofią i historią oraz na jej metody, ale właśnie pedagogiki katolickiej, czy mówiąc w dobie ekumenizmu - pedagogiki chrześcijańskiej. Twórczość naukowa Willmanna jest podstawowa i znacząca w tym względzie, gdyż charakter jego prac, jak również specyficzna uwaga poświęcona problemom pedagogicznym, wskazują na niego zarazem jako na twórcę oryginalnej własnej koncepcji pedagogiki ogólnej, co potwierdza oparcie się na stylu analiz nad podstawami pedagogiki. Pojmował pedagogikę jako naukę stojącą na stanowisku realizmu (umiarkowanego) i budująca najbardziej ogólną teorię rzeczywistości wychowania, jako wskazującą na poszukiwanie logicznej, krytycznej i usystematyzowanej oraz ogólnie ważnej wiedzy. Ten Arystotelesowski rys z jednej strony syntetyzujący i dążący do ogólności, drugi natomiast analityczny i szczegółowy wydaje się najbardziej specyficznym dla uprawiania pedagogiki chrześcijańskiej i odkrywania jej tożsamości, którą charakteryzuje przeprowadzanie analiz problemów wychowania w ich integralności i wzajemnych relacjach, a także w ich spójności ${ }^{11}$.

Konkretnie u Willmanna mamy z jednej strony podkreślanie roli „idei” w procesach historycznych i wspólnotowych, z drugiej odniesienie się do „rzeczywistości”, co czyni z Willmanna specyficznego filozofa, który stara się łączyć i uwzględniać wymienione oba kierunki myślenia w ówczesnym myślowym klimacie niemieckim. Klimat ten zdaje się być zakreślony przez dwa pola będące swoistymi biegunami przeciwstawnymi: abstrakcyjnego idealizmu i surowego realizmu.

Nawiązując do tradycji klasycznego myślenia filozoficznego, do jego ducha, który jest ten sam w idealizmie Platona, jak i w realizmie Arystotele-

${ }^{10}$ Zob. tamże, s. 13-14.

${ }_{11}$ Zob. M. Nowak, Wychowanie religijne w pedagogice katolickiej XX wieku, „Paedagogia Christiana" 1/7 (2001), s. 43-69. 
sa, Willmann przyjmuje je jako zawierające integralną (organiczną) koncepcję życia, której poszukiwał badając także pisma myślicieli średniowiecza.

Zdaniem Willmanna pogodzenie dwu systemów wokół prawdy pełnej, globalnej jest dziełem filozofów chrześcijańskich. Szczególnym zaś spoiwem dla jego poszukiwań była wiara chrześcijańska i w oparciu o nią kształtująca się chrześcijańska koncepcja człowieka, życia i świata. Willmannowi wydawało się oczywiste, że chrześcijańska mądrość życiowa i mądrość wychowawcza stanowią również ważną podstawę wiedzy pedagogicznej.

Rodzice, zdaniem Willmanna, mylą dość często wychowanie z życiem rodzinnym, nauczyciele utożsamiają z nauczaniem i szkołą, wielu nawet teoretyków koncentruje swoją uwagę na praktyce i w gruncie rzeczy zaniedbywana jest odpowiedź na problem: Czym jest wychowanie?

Analizując zatem istniejące definicje wychowania, zauważył, że w wielu z nich brakuje uniwersalności, że zwracają one uwage jedynie na jakiś jeden aspekt, na przykład fizyczny, bądź intelektualny, bądź etyczno-religijny wychowania. Willmann zauważa też, że wychowanie jest działaniem, w którym biorą udział dwie osoby: wychowawca i wychowanek i że łączy się ono z pewną funkcją w życiu społecznym i tym samym przybiera charakter nie tylko indywidualny, osobowy, podmiotowy, lecz także społeczny i obiektywny.

Willmann podaje też swoją definicję, według której „wychowanie jest opiekuńczym, regulującym i kształcącym oddziaływaniem ludzi dojrzałych na rozwój dojrzewających, ażeby mogli mieć udział w dobrach, które sa podstawą życia społecznego". Tak rozumiane wychowanie zawiera w sobie kategorie: opieka, nauczanie/ksztatcenie, kierowanie, dyscyplina, cele i ideaty wychowawcze, instytucje społeczne. Sa to podstawowe kategorie pedagogiki i można je zaklasyfikować do dwu grup wyrażających dwojaki sens wychowania: podstawowy pedagogiczny i etyczny.

„Wychowanie" rozumiane w sensie ogólnym i podstawowym zawiera w sobie to wszystko, co odnosi się do organicznego wzrostu człowieka W rozwoju. W tej grupie kategorii możemy umieścić pierwszą triadę pojęć: opieka - nauczanie/kształcenie - kierowanie, która oparta jest o triadę psychologiczną: życie - poznanie - pożadanie. Druga triada jest triadą etyczną i tworzą ją takie kategorie jak: rozwój - ideały $i$ wartości - instytucje społeczne.

Zdaniem O. Willmanna, aby zbudować prawdziwą pedagogikę i realizować prawdziwe wychowanie, należy zwracać uwagę jednocześnie na każdą z sześciu wymienionych podstawowych kategorii, które stanowią bazę dla całej pedagogiki. Prawdziwe wychowanie i prawdziwa pedagogika charakteryzuje się tym, że te wszystkie podstawowe kategorie nie tylko współ- 
występują lecz wzajemnie się wspomagają i pozostają w organicznej więzi. Każda też z tych kategorii posiada swoją naturę, swoją wartość i własne zadania, których druga nie posiada i nie zastąpi.

Te dwa „pedagogiczne trójmiany”, z sześciu kategoriami wpisanymi i złączonymi z procesem wychowania, zawierają w sobie aspekty troski o: rozwój psychofizyczny, dyscyplinę zewnętrzną i wewnętrzną, formację kulturalna, cele i o instytucje społeczne. Ich obecność jest nieodzowna i komplementarna w procesie wychowania, a tam, gdzie jej brakuje, mamy do czynienia z radykalnymi koncepcjami wychowania (do nich Willmann zalicza pedagogikę indywidualistyczna, naturalizm, intelektualizm, autonomizm, nominalizm i monizm) $)^{12}$.

Za Stefanem Kunowskim można dodać, że w przypadku wychowania chrześcijańskiego niezwykle ważna staje się właśnie kwestia uświadomienia sobie jego uniwersalności. Jest to uniwersalizm, który można określić w dodatku jako wręcz „zaborczy”, w myśl stwierdzenia świętego Justyna (ok. 100 - ok. 163/167), który podkreślał, że do chrześcijan należy to wszystko, co kiedykolwiek powiedziano lub uczyniono dobrego. Dlatego też ks. Konstanty Michalski zauważał w Katolickiej idei wychowania, że katolicyzm uznaje i akceptuje każdą prawdę i każdą zdobycz naukowa, niezależnie od kogo by pochodziła, jeśli odnajduje w niej obecność prawdy i dobra, co samo przez się już powoduje ten uniwersalizm naukowy i filozoficzny, w którym św. Augustyn sięga po prawdy zauważone przez Platona, a św. Tomasz z Akwinu po prawdy odkryte przez Arystotelesa ${ }^{13}$.

W tym sensie tożsamość i specyfikę pedagogiki chrześcijańskiej, odnosząc się do mojej koncepcji pedagogiki otwartej, można upatrywać w odniesieniu do jeszcze jednej perspektywy w badaniach, o której papież Jan Paweł II stwierdzał, mówiąc między innymi o specyfice uniwersytetów katolickich związanej z ich powszechnościq i otwarciem na wszystko ${ }^{14}$.

W tej linii wyodrębniania tożsamości pedagogiki chrześcijańskiej można wskazać, że pozostaje ona $\mathrm{w}$ dialogu $\mathrm{z}$ innymi dyscyplinami wiedzy i subdyscyplin pedagogicznych w szczególności, że podejmuje i chce podejmować wymianę doświadczeń badawczych i także wspólne badania z innymi przedstawicielami innych subdyscyplin pedagogicznych, chce jednak na tej bazie iść jeszcze dalej - odnieść swoje analizy do jeszcze jednej per-

12 Zob. tamże, s. 49-59.

${ }^{13}$ Zob. K. Michalski, Katolicka idea wychowania, w: Katolicka myśl wychowawcza, Poznań 1937, s. 25.

${ }^{14}$ Zob. Jan Paweł II, Homilia w czasie liturgii stowa skierowana do środowiska Katolickiego Uniwersytetu Lubelskiego (1987), w: tenże, Pielgrzymki do Ojczyzny, Kraków 2005, s. 403-409. 
spektywy - związanej z transcendencją i otwarciem się na Boże Objawienie przybliżane dla dialogu z innymi naukami przez prace teologów.

Te analizy w istocie wydają się prowadzić, poza podejściem integralnym i poszukiwaniem uniwersalności, także do drugiego bardzo charakterystycznego aspektu, a mianowicie istoty i źródła wychowania tkwiącego w samym człowieku i wyrażającego się w urzeczywistnianiu swojego człowieczeństwa.

\subsection{Urzeczywistnianie osoby ludzkiej w wychowaniu jako wyznacznik specyfiki pedagogiki chrześcijańskiej}

Ludzką egzystencję wyznaczają doświadczenia lęku, cierpienia, śmierci i grzechu, jako swoiste zakłócenia ładu, za którym tęskni człowiek i ku realizowaniu którego zmierza. W takie doświadczenia i dążenia człowieka wpisuje się i wychodzi im naprzeciw pedagogika ujmująca człowieka w aspekcie istnienia i stawania się. W związku z tym najbardziej istotna dla pedagogiki staje się wiedza o tym, kim człowiek jest? Na to pytanie pedagogika nie jest w stanie udzielić odpowiedzi z samej siebie, co nie oznacza jednak, że nie jest autonomiczna.

Niestety, zwłaszcza od końca XIX wieku zauważamy niekorzystne w tym względzie dążenie każdej dyscypliny wiedzy do autonomii, co wyniszcza wzajemne relacje między dyscyplinami i dziedzinami wiedzy. A przecież dyscypliny wzajemnie od siebie zależą i zwłaszcza w wypadku pedagoga domagają się one uznania ich wzajemnych zależności. Doświadczenie skończoności świata prowadzi nas do poszukiwania tego, co wieczne i stałe, doprowadzając człowieka do kształtowania tego jego stanowiska wobec świata, które nazywamy światopoglądem ${ }^{15}$.

Światopogląd, zawierając w sobie spójne wyjaśnienie całego wszechświata, ale też życia ludzkiego w relacji do człowieczeństwa, do kosmosu, w sensie zaszeregowania dyscyplinarnego znajdując się blisko ontologii i filozofii wartości, wpływa na wszelkie pedagogiczne myślenie i działanie wychowawcze, gdyż to tam właśnie, gdzie pedagog dostrzega cel człowieka, tam też chce on go prowadzić ${ }^{16}$.

W tym sensie nie znajdziemy pedagogiki, która opierałaby się na jakichś jedynie subiektywnych założeniach. Nie jest też możliwa pedagogika wyzuta ze światopoglądu. Nie jest też możliwa pedagogika skoncentrowana

15 Zob. H. Rohde, Die Verwirklichung der Person. Grundlegung der christlichen Pädagogik, Freiburg-Basel-Wien 1963, s. 1-2.

16 Zob. Simon, Religion und Weltanschauung, „Der katholische Gedanke“ 36 (1936), s. $42 \mathrm{n}$. 
na samorealizacji (Selfishness), lecz jak słusznie zauważał Bogdan Suchodolski (1903-1992), własna realizacja nie może być wystarczającym celem wychowania. Własna autorealizacja nie może zachodzić bez odniesienia do jakiegoś celu, musi mieć swoje przeznaczenie i swój punkt dojścia. Takim przeznaczeniem osoby jest życie społeczne, w które wejdzie i które ubogaci, a jednocześnie którym będzie się ubogacała. Ale i ono nie może być ostatecznym celem dążeń ludzkich, lecz pomocą w dążeniu do celu, którego nie sposób postawić bez odniesienia do Boga, w myśl Augustyńskiego zdania: „Niespokojne jest serce człowieka, dopóki nie spocznie w Bogu”. Dla chrześcijanina światopogląd chrześcijański jest ostatecznym i zarazem uniwersalnym wyznacznikiem jego dążeń i jego postawy wobec siebie samego, wobec innych, świata i Boga ${ }^{17}$.

Słusznie zatem należy się chyba naprawdę dziwić, jak zauważa Hubert Rohde, że podczas gdy w pozachrześcijańskich koncepcjach wychowania nie spotkamy nigdy nawet intencji budowania pedagogiki wolnej od światopoglądu, takie natomiast dążenia znajdujemy w pracach wielu pedagogów deklarujących się jako chrześcijanie ${ }^{18}$.

$\mathrm{W}$ odniesieniu właśnie do takich niezrozumiałych $\mathrm{w}$ gruncie rzeczy niezrozumiałych reakcji niektórych pedagogów, możemy przyznać całkowitą rację Romano Guardiniemu, który stwierdzał, że „na groteskową zabawę wygląda z jednej strony przyjmować, że istnieje Bóg żywy, a z drugiej w działalności pedagogicznej zachowywać się tak, jakby go nie było"19.

Przyjście Chrystusa istotnie bowiem i definitywnie przemienia naszą sytuację także w odniesieniu do wychowania i sprawia, że staje się ono nie tylko wypadkową naturalnych możliwości człowieka wychowywanego i wychowawcy, lecz odnawia człowieka w jego człowieczeństwie „czyniąc wszystko nowe" (Ap 21,5). W taki też sposób chrześcijański obraz człowieka i jego człowieczeństwo nie są tożsame z humanistycznym obrazem człowieka, ale to nie oznacza, że ten ludzki obraz w jakikolwiek sposób pomniejsza Boski obraz człowieka lub go wyklucza ${ }^{20}$.

Można ten fakt interpretować przez odniesienie się do tajemnicy Osoby Jezusa Chrystusa, będącego w pełni Bogiem i w pełni człowiekiem. W wychowaniu chrześcijańskim należałoby widzieć możliwości urzeczywistniania swojego człowieczeństwa zarówno w wymiarze naturalnym, jak i nadprzyrodzonym.

\footnotetext{
17 Zob. H. Rohde, dz. cyt., s. 2.

18 Zob. tamże.

19 R. Guardini, Grundlegund, Würzburg, s. 20.

20 Zob. H. Rohde, dz. cyt., s. 3.
} 
W istocie rzeczy mamy jakby dwa dojrzewania i dwie doskonałości. Oba dojrzewania i obie doskonałości idą - zdaniem K. Wojtyły - „najzupełniej w parze, dokonują się równocześnie, jakkolwiek z Objawienia wiadomo, że dojrzewanie człowieka do Boga ma swój korzeń i swój początek w nadprzyrodzonym zarodku bytu ludzkiego - w łasce. Bez tego zabrakłoby człowiekowi sił, nie mógłby niejako dorównać Temu, do którego ma dojrzewać, dojrzewając równocześnie do pełni człowieczeństwa"21.

Zdaniem Karola Wojtyły, chociaż „doskonałość zawsze jest humanistyczna, wewnętrzna i ludzka", to równocześnie dokonuje się nie tylko siłami naturalnymi, suponuje specjalną pomoc ze strony Boga, zwaną w religii chrześcijańskiej łaską. Łaska jest konieczna w dążeniu do świętości, która nie stanowi celu sama w sobie i jeśli ten proces jej osiagania nazwiemy sakralizacja, to jest ona przyporządkowana spirytualizacji-uduchowieniu osoby.

A zatem istotą wychowania nie będą ani etyczne wartości (czy etyczna doskonałość), ani wykształcenie i poznana prawda, lecz urzeczywistnianie człowieczeństwa (jak na to wskazują definicje wychowania Klausa Schallera, ks. Janusza Tarnowskiego czy Jana Pawła II).

Przypomnijmy zatem definicję wychowania sformułowaną przez K. Schallera: „wychowanie są to sposoby i procesy, które istocie ludzkiej (als Mensch geborenem Wesen) pozwalają odnaleźć się w swoim człowieczeństwie", powtarzaną zresztą w pracach ks. Janusza Tarnowskiego ${ }^{22}$. Jej zaś dopełnieniem może być definicja wychowania podana przez Jana Pawła II, który na pytanie: czym jest wychowanie?, odpowiada w języku personalistycznym: ,Wychowanie jest przede wszystkim obdarzaniem człowieczeństwem - obdarzaniem dwustronnym. Rodzice obdarzają swoim człowieczeństwem dojrzałym nowo narodzonego człowieka, a ten z kolei obdarza ich całą nowością i świeżością człowieczeństwa, które ze sobą przynosi na świat" (LdR 16) ${ }^{23}$.

W tych definicjach:

1) najpierw wyłania się kategoria (koncepcja) obrazu człowieka i dążenie do urzeczywistniania swojego człowieczeństwa. Działalność wychowawcza, zarówno ta wobec samego siebie, jak i wobec innych, w swojej istocie posiada swoje źródło identyfikowane przez Guardiniego z pewnym impulsem i pewną energią, które swoje źródła mają w dogłębnej

${ }^{21}$ K. Wojtyła, Właściwa interpretacja nauki o szczęściu, „Tygodnik Powszechny” 36 (1957), s. 11.

22 J. Tarnowski, Jak wychowywać?, s. 64-67; tenże, Pedagogika dialogu, w: B. Śliwerski (red.), Edukacja alternatywna, Kraków 1992, s. 120.

23 Jan Paweł II, List do Rodzin, Poznań 1994, s. 58. 
istocie człowieka, a które w kontekście chrześcijaństwa czy też wiary religijnej możemy odnieść ostatecznie do nieskończonego bytu samego Boga (obraz Boga w człowieku).

A zatem najpierw jest kategoria obrazu wewnętrznego (das Bild), inaczej obrazu istotowego naszego człowieczeństwa, związanego z niepowtarzalnym istnieniem każdej osoby ludzkiej. Niestety ideologiczna laickość zrodziła wiele problemów współczesnemu człowiekowi, zwłaszcza związanych z możliwością akceptacji i przyjęcia obrazu wewnętrznego jako zadanego człowiekowi w akcie stwórczym przez Boga (jak zauważał to m.in. Wolfgang Klafki) ${ }^{24}$.

Nie oznacza to jednakże, że takiej specyfiki (od Stwórcy) każdego ludzkiego istnienia nie ma i że nie trzeba jej uważać za podstawowy rys tożsamościowy i podstawę działalności wychowawczej, pozwalającej na urzeczywistnianie swojego człowieczeństwa. Odniesienie się do kategorii obrazu wewnętrznego (das Bild), inaczej obrazu istotowego naszego człowieczeństwa, wiąże się z niepowtarzalnym istnieniem każdej osoby ludzkiej. Odpowiednio do tej kategorii obrazu, podstawą i istotą wychowania jest własna aktywność - praca samowychowawcza, rozumiana jako urzeczywistnianie własnego, całkowicie indywidualnego obrazu istotowego - własnego człowieczeństwa;

2) poza obrazem istotnym, poza także własną podmiotowościq, staje się konieczne odniesienie się do otaczającego wychowanka świata rzeczy, a więc do obiektywnej rzeczywistości przedmiotowej, otwarcie na nią, gotowość przyjęcia jej, a nawet oddania sie jej aż do postawy służby wnoszonym przez nią wartościom.

Dla zrozumienia tego faktu możemy odnieść się do ujęcia wychowania według Stefana Kunowskiego, jako ukierunkowanego wszechstronnie rozwoju młodzieży w zakresie kształtowania pełni jej osobowości i przygotowania do życia $\mathrm{W}$ społeczeństwie. $\mathrm{W}$ procesie tym ma miejsce wychowawcze wyprowadzanie ze stanu naturalnego do wyższego stanu kulturalnego, a to na skutek dokonywania się wewnętrznej przemiany psychicznych dyspozycji człowieka, powodujących, że:

- w procesie personalizacji następuje zamiana postawy egoistycznej na górującą nad nią postawe altruistyczna;

- jednocześnie w procesie socjalizacji ustępuje początkowe nastawienie nostyczne (od nos - my) - przeciwstawiające sobie grupy na my

${ }^{24}$ Zob. W. Klafki, Pädagogisch-dialektische oder anthropologisch-existenzphilosophische Grundlegung der Erziehungswissenschaft, „Zeitschrift für Pädagogik“ 4 (1958), s. 213-361. 
i oni - na rzecz nastawienia illistycznego (od illi-oni), a więc służebnego zaangażowania się we wspólnocie ${ }^{25}$.

\section{Specyfika pedagogiki chrześcijańskiej jako integracja ciała i duszy, wychowania w kategoriach humanizacji czlowieka i jego chrystianizacji}

Możemy zatem stwierdzić na tym etapie naszych analiz, że w pedagogice chrześcijańskiej, jak ujmował to papież Jan Paweł II w swoim przemówieniu do Instytutu Katolickiego w Paryżu z dnia 1 czerwca 1980 roku, podejmuje się badania, aby „ujednolicić egzystencjalnie w pracy intelektualnej dwa porządki rzeczywistości, które często próbuje się przeciwstawiać jakby były antytetyczne: poszukiwanie prawdy oraz pewność, że już się zna źródło prawdy"²6.

Z tych też racji dla wychowawcy chrześcijańskiego człowiek ukazuje się jako osoba, w całej rzeczywistości swojego człowieczeństwa, co sprawia, że takie wychowanie staje się realistycznym i bierze pod uwagę człowieka w jego niepowtarzalności, jedyności, oryginalności - tak jak został pomyślany i stworzony przez Boga.

Wychodząc $\mathrm{z}$ tych założeń, przyjmuje się jako podstawę w pedagogice człowieka jako osobę złożoną z ciała i sfery duchowej posiadającej dominację nad sferą ciała - jako „samoposiadający się duch” - jak ujmował to Guardini. Urzeczywistnianie się człowieka w jego człowieczeństwie w ujęciu chrześcijańskim nie jest faktem natury, lecz zadaniem. Człowiek powinien urzeczywistniać siebie w wyniku wolnej, pozytywnej decyzji jako podmiot, w relacji z innymi (z wychowawca) i otaczającym go światem.

Pewną pomocą może nam służyć w wyjaśnieniu tego faktu teoria warstwicowa Stefana Kunowskiego, w której oprócz podstawowych dynamizmów rozwoju, takich jak bios, ethos, agos i los, na szczególną uwagę zasługują związane z nimi funkcje, to znaczy to, co może/powinien czynić wychowawca? Jakie są jego zadania i zobowiązania związane z wychowaniem?

Funkcje te są podyktowane koniecznością odpowiadania przez wychowawce na potrzeby rozwojowe wychowanka w obliczu tak zwanych stałych potrzeb już nabytych (warstwowych). Łączą się one z kolejnymi warstwami rozwoju człowieka, przebiegającego od warstwy biologicznej

${ }^{25}$ Zob. S. Kunowski, dz. cyt., s. 170-171; M. Nowak, Teorie i koncepcje wychowania, Warszawa 2008, s. 302.

${ }^{26}$ Jan Paweł II, Przemówienie do Instytutu Katolickiego w Paryżu, 1 czerwca 1980 r., nr 4., tekst m.in. w: S. Urbański (red.), Uniwersytety w nauczaniu Jana Pawła II (1978-1988), t.1, Warszawa 1999. 
(sanare) i psychologicznej (edocere), poprzez socjologiczną (educere), kulturologiczną (educare), do duchowej (initiare) i chrześcijańskiej (christianisare $)^{27}$.

Kolejno przedstawiając te funkcje możemy wskazać nade wszystko na:

- funkcje 'sanare', która dotyczy opieki wychowawcy nad „biosem” wychowanka, czyli nad jego sferą biologiczną i psychologiczna, a więc nad życiem i zdrowiem organizmu. Wychowawca może realizować tę funkcję przez podsycanie energii i żywotności wychowanka, przez wzmacnianie jego siły życiowej, zdrowia, radości i motywacji do życia. Ta funkcja, rozszerza się na następną;

- funkcję 'edocere', obecną zwłaszcza w sferze psychologicznej, która dotyczy zarówno obowiązku dostarczenia wartościowego materiału poznawczego ze względu na budzące się zdolności poznawcze i racjonalność wychowanka, jak i pobudzania go do rozwoju myślenia. Wszechstronne wychowanie umysłowe (intelektualne), które powinno prowadzić do tego, aby przez nauczanie, informowanie, poznanie naukowe, budzenie zainteresowań i ciekawości poznawczej powodować w wychowanku pragnienie dążenia do najwyższych wartości, z których najbardziej istotną jest prawda ${ }^{28}$. Powinno to więc być wprowadzanie wychowanka w relację do prawdy;

- funkcja educere dotyczy działań wychowawcy, które mogą być skierowane na złożony kontekst społeczny, a więc jest skierowana również na trzeci element w relacji wychowawczej, czyli „sytuację wychowawczą". To wyciaganie, wydobywanie wychowanka ze stanu naturalnego i podnoszenie na wyższy poziom moralny. Polega to na pobudzaniu wychowanka do wyzwolenia się z egoizmu i indywidualizmu, na otwieraniu go na społeczność, na wspólnotę osób i bycie dla drugich. Funkcja educere łączy się z procesem socjalizacji, uspołecznienia, wprowadzenia w wartości i normy społeczne oraz formowania sumienia i przygotowania do pełnienia funkcji oraz ról społecznych i zawodowych;

- funkcja educare oznacza działanie na rzecz szeroko pojętej ,,inkulturacji”, czyli przyjęcia i aktywnego włączenia się w tworzenie i przeżywanie wartości kultury, zarówno tej najbliższego otoczenia, jak i ojczystej i narodowej oraz religijnej. Z tą funkcją można łączyć „wy-

27 Zob. S. Kunowski, dz. cyt., s. 195-198; zob. M. Nowak, Teorie, s. 309-311.

${ }_{28}$ Zob. obszerniej: M. Gogacz, Podstawy wychowania, Niepokalanów 1993, s. 7; zob. także S. Kunowski, dz. cyt., s. 8-9; M. Nowak Znaczenie wartości w procesie wychowania, w: K. Popielski (red.), Człowiek - wartości - sens. Studia z psychologii egzystencji, Lublin 1996, s. 98; J. Gajda (red.), Wybrane problemy animacji kulturalnej, Lublin 1993. 
chowanie patriotyczne” i „pedagogikę ideału”. Istotne byłoby tutaj stymulowanie aktywności do przybliżającej do tych wartości, bardziej w sensie animacji kulturalnej, aniżeli przekazywania treści;

- funkcja initiare. Wprowadzanie wychowanka w problemy natury filozoficznej, światopoglądowej, religijnej i teologicznej, mające na celu odpowiedź na pytania o sens i cel ostateczny życia człowieka, o cierpienie. Chodzi zwłaszcza o przygotowanie wychowanka do ufnego projektowania swojego przyszłego życia ${ }^{29}$;

- funkcja christianisare. To zadanie „chrystianizacji” wobec wychowawcy chrześcijańskiego w ramach realizacji wychowania chrystocentrycznego, które dąży do doprowadzania wychowanka do spotkania z Chrystusem i do życia w duchu Chrystusa. W tej właśnie funkcji najwyraźniej możemy zauważyć fakt przekroczenia, transgresji wymiaru tylko naturalnego, czy nawet czysto ludzkiego i ziemskiego oraz otwarcie się na rzeczywistość transcendentalną.

To tutaj możemy zauważyć konkretne przekonstruowanie się procesu wychowawczego i jego celowości z perspektywy naturalnej w perspektywę nadnaturalną (nadprzyrodzoną), która nie tylko dopełnia naturalny proces wychowania człowieka, ale go otwiera na nowe perspektywy i rzeczywistość.

Funkcja christianisare łączy bowiem w sobie (integruje) wszystkie wyżej wymienione, w pewnym sensie wywyższając i sublimując je, a przez to przypisując im jeszcze wyższe znaczenie:

1) Funkcja sanare jest tu widziana jako uzdrawiające działanie łaski, leczące skażoną naturę ludzką i dające poczucie wolności dzieci Bożych;

2) Funkcja edocere - prowadzenie do Boga, źródła prawdy i budzenie świadomości wiary;

3) Funkcja educere - wprowadzenie wychowanka do społeczności wiernych w Kościele i włączenie go do apostolatu;

4) Funkcja educare ma wprowadzać na drogę naśladowania Chrystusa, który jest „personalnym symbolem wartości” i uosobieniem najwyższego ideału człowieka.

5) Funkcja initiare jest pojmowana w chrześcijaństwie jako wprowadzenie w sakramenty wtajemniczenia chrześcijańskiego i w światopogląd chrześcijański.

29 Zob. Th. Eschenburg, Über Autorität (1965), w: E. E. Geißler (Hrsg.), Autorität und Freiheit, Bad Heilbrunn 1977, s. 6-8. 
Ostatnia funkcja powinna uwzględniać w sposób szczególny także potrzeby rozwojowe dziecka, jego zdolności percepcyjne i potrzeby związane $\mathrm{z}$ „,chrystianizacją życia”"30.

Podsumowując przeprowadzone wyżej analizy, chciałbym postawić je wobec pytania o cel takich rozważań. Oczywiście, ten cel nasuwa się bardzo szybko w związku z naszą tożsamością, a w wypadku czasopisma „Pedagogia Christiana" także z tożsamością czasopisma i związanych z nim autorów i czytelników.

Jest jednak jeszcze inna perspektywa tego zagadnienia, na którą chciałbym wskazać powołując się na stanowisko Josepha Adelmanna, który w odniesieniu do omawianych wyżej analiz Romano Guardiniego poświęconych tożsamości wskazuje na dwa powody poszukiwania tożsamości czy też specyfiki pedagogicznej (das Spezifisch-Pädagogische) w pedagogice:

1) z powodu zainteresowania się istotq działalności wychowawczej, a tym samym dotarcia do tego, co podstawowe w pedagogice, co może być naprawdę istotne, konieczne i oryginalne;

2) a także intencja dotarcia do przekształcenia autonomii absolutnej $\mathrm{w}$ autonomie względna, przechodząc od aktualnego wyizolowania się pedagogiki jako autonomicznej, do wpisania i uporządkowania autonomicznej wiedzy pedagogicznej w pewnej całości wiedzy o człowieku i jego wszechstronnym rozwoju wychowawczym ${ }^{31}$.

Za J. Speckiem możemy wskazać na wartość takich analiz i myślenia, którego cel wyraża w słowach: ,żebyśmy znowu byli ludźmi, związanymi $\mathrm{z}$ istotą naszego bytu, abyśmy znowu stanęli wobec rzeczy, wobec pełnej rzeczywistości, abyśmy z respektem potrafili odczuwać istotę tych rzeczy"32.

Temu celowi chcemy służyć przez podjętą kwestię tożsamości pedagogiki chrześcijańskiej.

\section{The Identity of Christian Education (Summary)}

The article undertakes the problem of the identity of the Christian Pedagogy, which although obvious, when we are dealing with a discipline of knowledge with

${ }^{30}$ S. Kunowski, dz. cyt., s. 197-198; zob. także M. Nowak, Teorie, s. 310-312; R. Guardini, Freiheit, Gnade, Schicksal. Drei Kapitel zur Deutung des Daseins, München 1979, s. 60.

${ }^{31}$ Zob J. Andelmann, Romano Guardini: Grundlegung einer Bildungs- und Erziehungslehre, „Pädagogische Welt" 9 (1955), s. 643; także R. Guardini, Grundlegung, Würzburg, s. $10-11$.

32 J. Speck, Guardinis Gegensatzlehre und das sogenannte, dialektische ' Denken in der Pädagogik (Auseinandersetzung mit ,Der Gegensatz '), „Vierteljahresschrift für wissenschaftliche Pädagogik“ 40 (1964), s. 89-115, 187-226. 
its legacy and tradition, however, this is not just an academic challenge (undertaken, inter alia, by M. Buber and R. Guardini), but allows for the development of our thinking about the man in general and his advisability.

The investigation for the understanding of human existence, it requires explicit educational aid, which features within the meaning of the Christian should become: integrity and universality, as well also the understanding of education as a reality of humanity of the human person. So understood the relevant trademarks and Christian identity determinants of the pedagogical thought also require clarity in our approach to the world, that we call ideology and giving a coherent explanation of our life, the world, the relationship to the self, to others and to God.

In such conditionings the Christian educator appears as a person who, in all reality of his humanity, and the education becomes a realistic taking into account the human being in its uniqueness, its originality, such as it was conceived and created by God. So educated man, compatible with the essence of his being, should be able to stand up to the full reality and feel her essence. Only then you can talk about results achieved the Christian education and the advisability of a proper Christian pedagogy.

Keywords: Christian education; Christian pedagogy; reality of humanity of the human person; coherent explanation of life.

\section{Tożsamość pedagogiki chrześcijańskiej (Streszczenie)}

Artykuł podejmuje problem tożsamości pedagogiki chrześcijańskiej, który aczkolwiek oczywisty, gdy mamy do czynienia z dyscypliną wiedzy posiadająca swój dorobek i tradycję badawczą, to jednak nie jest tylko problemem akademickim (podejmowanym m.in. przez M. Bubera i R. Guardiniego ), lecz pozwala na rozwój naszego myślenia o człowieku w ogóle i jego celowości.

Dochodzenie do zrozumienia ludzkiej egzystencji wymaga wyraźnej pomocy wychowawczej, której cechami w rozumieniu chrześcijańskim powinny się stawać: integralność i uniwersalność, a także rozumienie wychowania jako urzeczywistnianie człowieczeństwa osoby ludzkiej. Tak rozumiane istotne znaki rozpoznawcze i wyznaczniki tożsamości chrześcijańskiej myśli pedagogicznej wymagają także wyrazistości naszego stanowiska wobec świata, które nazywamy światopoglądem, a dającego spójne wyjaśnienie naszego życia, świata, relacji do siebie, do innych i do Boga.

W takich uwarunkowaniach wychowawcy chrześcijańskiemu ukazuje się wychowanek jako osoba, w całej rzeczywistości swojego człowieczeństwa, a wychowanie staje się realistycznym wzięciem pod uwagę człowieka w jego niepowtarzal- 
ności, jedyności, oryginalności, takim jak został on pomyślany i stworzony przez Boga. Tak wychowany człowiek, zgodny z istotą swojego bytu, powinien potrafić stanąc wobec pełnej rzeczywistości i odczuwać jej istotę. Dopiero wówczas można mówić o osiaggniętych efektach wychowania chrześcijańskiego i celowości właściwej pedagogice chrześcijańskiej.

Słowa kluczowe: wychowanie chrześcijańskie; pedagogika chrześcijańska; urzeczywistnianie człowieczeństwa osoby ludzkiej; spójne wyjaśnienie ludzkiego życia. 